Check for updates

Cite this as: $B M J 2021 ; 372: \mathrm{m} 4953$ http://dx.doi.org/10.1136/bmj.m4953

Published: 18 January 2021

\section{Early management of unstable angina and non-ST segment elevation myocardial infarction: summary of NICE guidance}

Clarification-This NICE guideline summary (BMJ 2010;340:c1134, doi:10.1136/bmj.c1134) has now been superseded by a summary of updated guidance at www.bmj.com/content/371/bmj.m476o. 